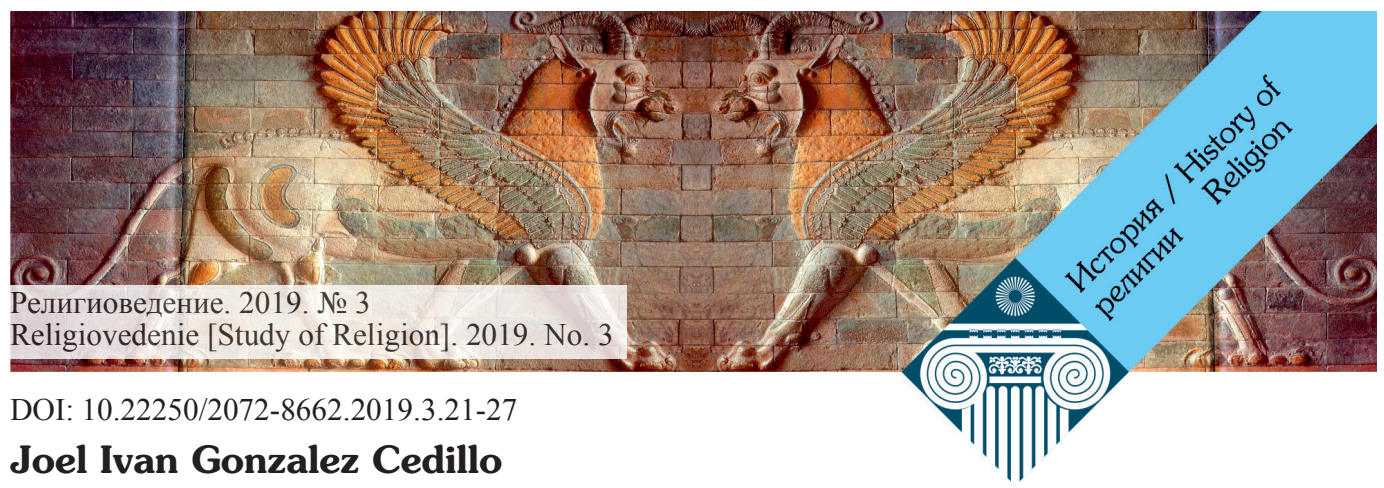

St. Petersburg State University

1/3 Smolny St., St. Petersburg, Russian Federation, 191060

ivangzz.ced@gmail.com

\title{
Evangelicalism as a Political Mobilizer in Latin American Politics and the Reemergence of Conservative Governments
}

Abstract. Evangelicalism has experienced a rapid increase in Latin America the last four decades at the expense of Catholicism, as believers look for a more personal relation with God, a more practical religious life and detaching from the institutionality the Catholic Church represents. Due to the nature of Evangelicalism, believers started

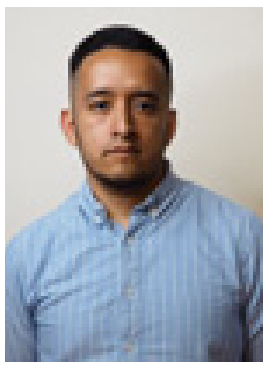
to get involved into the political life of their countries. The author analyses the use of discursive elements of Evangelicalism by conservative parties in Guatemala and Brazil to gain political power. Such phenomenon is reciprocal as Evangelical leaders take advantage of the exposure and reach they will get once conservative politicians gain power. The goal of the author is to visibilize the existing alliance between the Evangelical communities and conservative political parties in Latin America and the effects it has on secular democracies. The author gets to the conclusion that Latin American secular democracies that allow the participation of resourceful religious institutions or individuals in the political life risk the continuation of the secular democratic state.

Key words: Evangelicalism, conservatism, liberalism, fascism, Guatemala, ideology, propaganda, Jair Bolsonaro, Brazil

\section{Хоэп Иван Гонсапес Седиппо}

Санкт-Петербургский государственный университет

191060, Российская Федерация, г. Санкт-Петербург, ул. Смольного, 1/3

ivangzz.ced@gmail.com

\section{Евангепизация как попитический мобилизатор в патиноамериканской попитике и возрождение консервативных правитепьств}

Аннотация. В последние четыре десятилетия евангелизация в Латинской Америке стремительно развивалась за счёт католицизма, поскольку верующие стремятся к более личным отношениям с богом, к более «удобной» религиозной жизни и отстранению от институциональных возможностей, которые представляет католическая церковь. Из-за характера евангелизации верующие начали вовлекаться в политическую жизнь своих стран. Автор анализирует использование дискурсивных элементов евангелизации консервативными партиями в Гватемале и Бразилии для завоевания политической власти. Такое положение вещей является взаимовыгодным, так как евангельские лидеры получают доступ к широкой аудитории, когда к власти приходят консервативные политики. Целью автора является обзор существующего союза между евангелическими общинами и консервативными политическими партиями в Латинской Америке и его влияния на светскую демократию. Автор приходит к выводу, что латиноамериканские светские демократические системы, которые допускают участие религиозных институтов или отдельных лиц в политической жизни, рискуют будущим светского демократического государства.

Ключевые спова: евангеликализм, консерватизм, либерализм, фашизм, Гватемала, идеология, пропаганда, Яир Больсонаро, Бразилия 


\section{История религии / History of Religion}

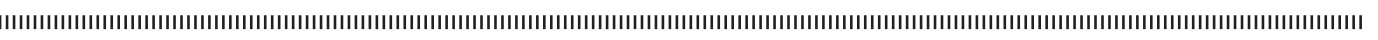

Conservative political forces in some Latin American societies have resorted to the use of Evangelical values as the central ideology of their political discourse. As such, those forces aim at mobilizing voters against the progressive governments or causes that had dominated the region since the early XXI c.

This article works on two hypotheses: 1) individuals with a significant lack of knowledge on a specific issue can be manipulated by ideology through the use of propaganda by groups with political interests, and due to their lack of knowledge, such individuals end up embracing extremist ideas; and 2) the use of religion to gain political power can result in religious extremism. Through a historical-political analysis of academic and journalistic sources on the spread and popularization of Evangelical Pentecostalism in Latin America, this work explores how the lack of knowledge or comprehension of progressive policies have facilitated the emergence and empowerment of groups that use Evangelicalism to promote a political conservative agenda.

\section{Expansion of Evangelicalism in Latin America}

Evangelicalism is a current within Protestantism that originated in the First Great Awakening in the XVIII c. in the United States and England. As part of the Reformation, Luther made emphasis on "the experience of personal assurance of forgiveness" rather than having a priest absolving the sinner; this personal and closer relation to God is central to Evangelicals [Smith, 1922, 626]. The Reformation also abolished the distinction between the clergy and laity, which eliminated the authoritative character of Christianity the Catholic church had had over the believers [Smith, 1922, 627].

Within Evangelicalism there are two currents known as Renewalism: Pentecostals and Charismatics (Neo-Pentecostals), the former are dominant in the Global South while the latter in the Global North. Charismatics are Christians of other denominations, Protestant, Catholic, Mormons, etc. who have taken up Pentecostal practices based on the centrality of the Holly Spirit [Lampman, 2006]. Pentecostals believe in miracles, divine healing and glossolalia. The majority of Evangelical leaders in the Global South considers the Bible should be interpreted literally (58\%) in comparison to the Global North (40\%); and are also more likely to believe in creationism, dismiss the theory of evolution, to have witnessed an exorcism or a revelation, or experienced glossolalia than those in the Global North.

Another practice in Evangelicalism is prosperity gospel, which is based on the idea that "God gives health and material prosperity to those with enough faith" [Lampman, 2006] and is founded on the doctrine of Arminianism that proposes all men can be saved through faith, challenging Calvinist predestination that claims only the previously chosen will be saved, regardless of their actions. This practice has been controversial as some pastors have amassed fortunes by telling believers the way to salvation is through tithe, the more substantial their tithe, the more grace they will receive.

Evangelicalism in the US is closely related to the Republican party and other more conservative currents; however, this religious sector has been in decline, going from $21 \%$ of the population in 2003 to $13 \%$ in 2017 . Some of these strictly conservative Evangelical sectors in US society are perceived as "toxic Christianity" for their political views and agenda that supports hate speech against non-Christians, oppression of women in society and their submission to men, and censorship of critics among their own ranks.

With financial and political support from the US government, Evangelicalism was exported into Latin America in the mid XIX c. as part of the Monroe Doctrine aimed at establishing American control over the region [Pastor Gómez, 2018, 3-4]. In the first decades of the XX c. the US government gave millions of dollars to build Evangelical churches in Latin America and support of Evangelical missionaries with the aim of weakening the Catholic church domination, stopping the advance of social movements of liberation, left-wing intellectualism and criticism of the US [Pastor Gómez, 2018, 5]. The plan paid off as data shows that in 1970 Catholics in Latin America started to decrease and went from $92 \%$ to $69 \%$ in 2014, while Protestantism (mostly Evangelical Pentecostals) moved from $4 \%$ to $19 \%$ in the same period.

The concern of the increase of Evangelical Pentecostalism as a political actor in Latin America is not only a threat to the secular state but also to the public education and health systems. The belief on divine healing and the performance of miracles combined with an existing discourse that promotes distrust in medical science (popularized in 


\section{История религии / History of Religion}

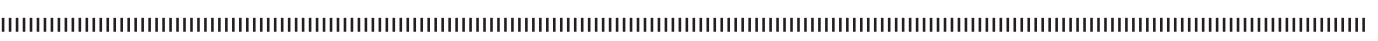

the US) give the conditions for the outbreak of curable diseases or the abandonment of medical treatment, as some pastors go as far as claiming they can heal cancer or HIV, while others tell vaccines are dangerous for humans as God created men and women with the ability to heal themselves from any disease.

Catholic Latin Americans convert into Evangelical Pentecostalism thanks to many reasons, among them the new models of neoliberal development introduced in the 90's and the new culture of consumption that came with it (after the fall of fascist dictatorships), the new information technologies that facilitated the spread of the Evangelical message via TV (Televangelists) and internet, as well as social movements like feminism, indigenism and sexual identities that challenged the domination of Catholic authorities [Parker, 2015, 5-14], as well as sexual abuse scandals in which some Catholic authorities have been involved.

Evangelicalism in Latin America has spread among the lower strata of societies and represents an adequate political mobilizer for conservative platforms that had been trying to win the vote of this sector from socialists. This sector felt threatened by the expansion of progressive movements like third wave feminism in the region, for which they blamed left-wing politics. The lack of actual information, misinformation on social media and extremism by some promoters of the movements definitely contributed to the rejection of citizens.

\section{Ideology and propaganda}

Ignorance is the source of any type of extremism, as when individuals ignore relevant aspects of their identity, history or their surroundings, they become easy targets of manipulation. Such manipulation occurs through the implantation of an ideology which is done by the use of propaganda.

$\mathrm{H}$. Cantril defined propaganda as the "expression of opinion or action by individuals or groups deliberately designed to influence opinions or actions of other individuals or groups with reference to predetermined ends" [Cantril, 1938, 217]. For A. Jewett propaganda is "the attempt on the part of a self-interested person or group deliberately to mislead and misinform the public in order to prevent, impede, or forestall an objective consideration of the facts involved in a public issue" [Jewett, 1940, 105]. Propaganda works because propagandists use words they know have an enormous emotional charge on their target population and will cause an immediate reaction. Jewett was able to identify that individuals should not be extraordinary intelligent to avoid falling for propaganda, they rather need to be informed of the facts propaganda is addressing [Jewett, 1940, 115].

Propaganda is aimed at influencing others' decisions or opinions, which is done by implanting an ideology on the target individual. Ideology was first defined by Destutt de Tracy as "the science of ideas" [Bychkov, 2017, 87]. For Marx and Engels ideology is "the way to perceive reality, consisting in the construction of an imaginary reality issued for reality itself" as well as a "false consciousness" [Bychkov, 2017, 87], and for Gramsci ideology refers to "the system of ideas that each person possesses, which does not depend on physiological causes but on historical-political ones" [Filippini \& Barr, $2017,7]$. Finally, Rossi-Landi identified there are two categories of ideology: 1. "ideology as a false consciousness (critical-negative meaning)" and 2. "ideology as a vision of the world (positive-descriptive meaning)" [Filippini \& Barr, 2017, 14]. From this we can conclude that ideology is the constructed system of ideas developed throughout the life of individuals and that obey their need to understanding and transforming their reality and that can be either a distorted representation of truth or a loyal representation of what is accepted as the common reality.

Conservative parties and groups in the region have teamed up with actors that have influence on the masses that need to be mobilized to vote. Evangelical leaders and conservative politicians needed each other in the pursuit of their interest in creating a society based on values they consider are the foundation of a moral society (based on a literal interpretation of the Bible) and that also follows the neoliberal economic model.

Latin American left-wing governments represented the class struggle and anticolonial fight for the national interests, such fight was not only in the economics but also in the social and cultural fields, something its critics call "cultural Marxism", which is 


\section{История религии / History of Religion}

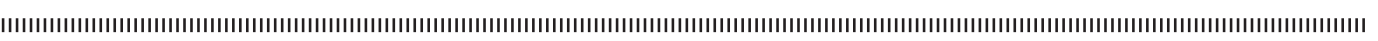

nothing but a set of movements that looks for the liberation of women, empowering of ethnic and sexual minorities and fighting systems of oppression that prevent citizens from fully developing as individuals in society. Third wave feminism represents all of these aims, and soon, conservative groups started to use it, as well as what they call "gender ideology", to spread fear among misinformed citizens making them believe there is an open war against "Christian values" and the model of the traditional family. The so called "gender ideology" is not an academic term, neither an ideology itself, it is however a political term used to discredit anti-discrimination policies and the extension of legal protection for women, ethnic and sexual minorities. Political discourse that uses this term claims feminists, socialists and Marxists are aggressively trying to destroy Western Christian societies by promoting uncontrolled immigration, multiculturalism, teaching sexual education at school and supporting abortion.

\section{The Advance of Evangelicalism in Guatemalan and Brazilian Politics}

Much work has been done on the presence of Evangelicals in the political life in Guatemala and Brazil, as well as the use of political discourse by Evangelical leaders or institutions in non-political spaces. This work will add an analysis of the latest events in Guatemala with president Jimmy Morales (2016) and in Brazil with president Jair Bolsonaro (2019) to the existing literature, their relation to Evangelical Pentecostalism and how such public religiosity is leading to religious and political extremism.

Political Evangelicalism came to power in Guatemala in 1991 under president Jorge Serrano who was an active member of a Christian organization "El Shaddai", that performed a national exorcism known as "Jesus is Lord of Guatemala" to free the country from an ancient curse [Freston, 1996, 24]. Guatemala has the largest share of Evangelicals in the region (41\%) as of 2017 and this is not only reflected on the de facto Evangelical line the supposedly secular government is following, but also on the presence of powerful religious figures in communities throughout the country, like pastor Cash Luna who preaches the prosperity gospel and has amassed a fortune and built a monumental church in Guatemala City with capacity for 12,000 people. More evident links between Guatemalan politics and Evangelical Pentecostal leaders were seen in 2007 in the internal elections of the Partido Patriota to elect the candidate for presidency, then the National Association of Evangelical Ministers decided to publicly support Otto Perez Molina and call for members of the Evangelical church to vote for him. Though he did not win the nomination in 2007, he won the presidential elections of 2012 and served as president of the country until 2015.

During Morales' term as president of Guatemala, Evangelicals in congress have had power to influence the lives of non-religious and non-Christian citizens. On November 2017, a deputy of the party Unidad Nacional de la Esperanza (UNE) presented a bill to create the Day of the Evangelical Church, though later that day she withdrew it. On September 2018 the Guatemalan congress voted to banning a Swedish heavy metal band from entering the country to perform, claiming the band offends the good morals of Christian Guatemalans. Some deputies considered the band is part of a Satanic movement trying to influence their society. This was a clear demonstration of censorship and an attack on freedom of speech and consciousness based on what the deputies considered “Christian values". In 2017, Elvis Molina, a lawyer and Evangelical pastor presented the project of bill 5272 that immediately got the support of the Evangelical party VIVA, such bill would give jail sentences up to five years for miscarriage, prohibit same sex marriage and legalize homophobia.

Brazil is the country in which Evangelical Pentecostalism has advanced and penetrated the most in the region. Brazilian Pentecostals "have a lot of money, over 42 million followers and their own construction companies to build mega churches like the Universal Church at Sao Paulo with capacity of 10,000 people" [Pastor Gómez, 2018, 11]. As part of his PhD research, Paul Freston wrote in 1997 Pentecostalism in Brazil was seen as "...the source of effective change because it builds communities of discontinuity and transformation...confronts machismo more effectively than feminism...represents the emergence of a new egalitarian society" [Freston, 1996, 24].

Since 1986 the number of openly Pentecostal politicians in Brazilian congress increased as Evangelical groups presented candidates to elections [Freston, 1996, 24-25]. Brazilian Evangelical Pentecostals focus their attention on civil issues like keeping control 


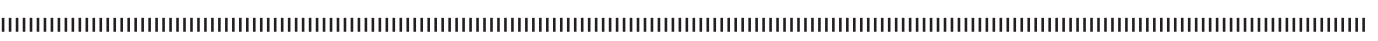

of Brazilian mass media or at least maintain their predominance [Freston, 1996, 25]. The Universal Church of the Kingdom of God is today the largest Evangelical congregation in Brazil, founded in 1977 in Rio de Janeiro by Edir Macedo who was "key in the election of his nephew Marcelo Crivella as major of Rio de Janeiro" in 2016; Crivella has cut funds for the popular cultural events like the carnival, the gay pride demonstration and Afro-Brazilian cults [Pastor Gómez, 2018, 10]. Evangelicals had given political support to ex-president Lula da Silva, but in 2016 the segment in congress known as the "The Bible bench" was key in the impeachment of Dilma Rousseff [Pastor Gómez, 2018, 10].

Macedo owns the second largest TV network in Brazil called "Rede Record" and in 2016 he put it at the disposal of Bolsonaro's campaign and to whom the Evangelical vote was key in winning the election [Pastor Gómez, 2018, 11]. In January 2019, already in Bolsonaro's government, the minister of the Woman, Family and Human Rights, Damares Alves, declared she acknowledges the secularity of the State, but she is "a hardcore Christian", and so a new era had begun. Bolsonaro's Evangelical government has an open confrontation against what they consider indoctrination of the educational system by Marxist ideology, according to the Minister of education Ricardo Velez. Velez praises the military dictatorship and together with Bolsonaro and Evangelical politicians, support the movement "Schools without party" that calls students to record and denounce professors who in their teaching "include values out of the established order", which is clear censorship and limit to academic freedom.

In relation to international relations, Bolsonaro's government opened a diplomatic office in Jerusalem on March 31, 2019, in a move to demonstrate its close ties to Israel, as Evangelical Pentecostals support the state of Israel for Biblical reasons. In a similar way, Guatemala opened an embassy in Jerusalem in May 2018. Both governments have had a close relationship to D. Trump's administration, one that has a strong influence of the Evangelical American sector and is represented by Vice President Mike Pence.

Freston claimed that "there are several factors which suggest that Protestant, and especially Pentecostal religion may be helpful for democracy, or at least neutral in its effects. Unlike Islamic fundamentalism, it is a product of the voluntarist tradition and thus divided" [Freston, 1996, 26]. However, Evangelical Pentecostalism is considered a fundamentalist movement in Christianity by scholars and journalists [McVicar, 2016, 1-2]. Though there is not a definition of extremism in Brazilian and Guatemalan law, it is possible to conclude that Evangelical Pentecostalism, when used to gain or maintain political power, has similar characteristics of well-known and studied types of religious extremism like Wahhabism or Salafism. Such movements look for the dominance of their religious interpretation of Islam on other Muslims and non-Muslims in their societies, promote the superiority of religion over science, advocate for censorship and persecution of critics, as well as public and private behavior based on their perception of Islamic morals that dictate how citizens must live their lives regardless of their relation to religion.

The lack of a social policy attractive for low strata voters and the advance of progressive movements backed by left wing governments has pushed conservative politicians closer to Evangelical leaders looking for votes in exchange of a discourse that claims to protect Christian values. Evangelical leaders see in this approach an opportunity to create legislation based on their perception of Christian morality. Such "marriage" between religious powerful and influential groups and the State is unhealthy for democracies as such groups will start legislating based on their perception of good and evil, limiting basic freedoms and destroying the very system they used to gain control. To avoid this, effective legislation and an active civil society that protects the separation between religion and politics in the secular state is needed. This does not mean censoring personal religious expressions but rather to keep the personal private to protect the continuation of democracy in multi-confessional societies.

\section{Бибпиографический список}

1. Бычков, А.А. Социологическая интерпретация понятий «идеология» и «идеологический проект» / А.А. Бычков // Социальная Компетентность. Иркутский национальный исследовательский технический университет. - 2017. - Вып. 2. - № 1 (3). - С. 87-89. 


\section{История религии / History of Religion}

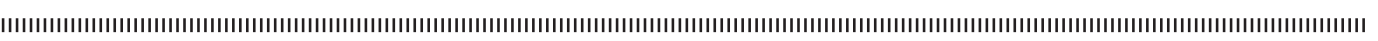

2. Cantril, H. Propaganda Analysis / H. Cantril // The English Journal. - 1938. - № 27 (3). P. 217-221.

3. Cariboni, D. Evangélicos en Guatemala al Borde de "Legalizar la Homofobia" [Электронный pecypc] / D. Cariboni // El Pulso. - URL: https://elpulso.hn/evangelicos-en-guatemala-al-bordede-legalizar-la-homofobia/ (дата обращения 01.05.2019).

4. Castañeda, J.M. Diputada se Arrepiente de Promover el Día de la Iglesia Evangélica [Электронный ресурс] / / J.M. Castañeda // SOY502. - URL: http://www.soy502.com/articulo/diputadaarrepiente-promover-dia-iglesia-evangelica-63338 (дата обращения 01.05.2019).

5. Corrales, J.A Perfect Marriage: Evangelicals and Conservatives in Latin America [Электронный pecypc] / J.A. Corrales // The New York Times. - URL: www.nytimes.com/2018/01/17/opinion/ evangelicals-politics-latin-america.html (дата обращения 26.04.19).

6. De Jong, A. Protestants decline, more have no religion in a sharply shifting religious landscape (POLL) [Электронный ресурс] / A. De Jong // ABC News. - URL: http://www.abcnews.go.com/ Politics/protestants-decline-religion-sharply-shifting-religious-landscape-poll/story?id $=54995663$ (дата обращения 23.04.2019).

7. El Papa Francisco y la Religión en Chile y América Latina. Latinobarometro [Электронный pecypc]. - URL: http://www.cooperativa.cl/noticias/site/artic/20180112/asocfile/20180112124342/ f00006494_religion_chile_america_latina_2017.pdf (дата обращения 30.04.19).

8. Evangelical Beliefs and Practices [Электронный ресурс] // Pew Research Center. - URL: http:// www.pewforum.org/2011/06/22/global-survey-beliefs/ (дата обращения 16.04.19).

9. Evangélicos de Guatemala optan por apoyar políticamente a partido de general retirado [Электронный ресурс] // ACI Prensa. - URL: www.aciprensa.com/noticias/evangelicos-de-guatemalaoptan-por-apoyar-politicamente-a-partido-de-general-retirado (дата обращения 01.05.2019).

10. Filippini, M. Ideology. In Using Gramsci: A New Approach / M. Filippini, P. Barr. - London: Pluto Press, 2017. - P. 4-23.

11. Freston, P. Evangelicalism and politics: A comparison between Africa and Latin America / P. Freston // Transformation. - 2001. - № 14 (1). - P. 23-29.

12. Galarriaga, N. La nueva ministra de Familia de Brasil: "Las niñas, de rosa; los niños, de azul" [Электронный ресурс] / N. Galarriaga // El País. - URL: elpais.com/internacional/2019/01/04/ actualidad/1546602274_498637.html (дата обращения 03.05.2019).

13. Guatemala prohíbe la entrada a una banda sueca de metal por "inmoral" у "satánica" [Электронный ресурс] // RT. - URL: http://actualidad.rt.com/actualidad/290024-guatemala-prohibirbanda-marduk-suecia-satanico (дата обращения 01.05.2019).

14. Jewett, A. Detecting and Analyzing Propaganda / A. Jewett // The English Journal. - 1940. № 29 (2). - P. 105-115.

15. Lampman, J. Renewalist impact grows [Электронный pecypc] / J. Lampman // The Christian Science Monitor. - URL: http://www.csmonitor.com/2006/1012/p13s02-lire.html (дата обращения 16.04.2019).

16. López, V.D. Educación en el Brasil de Bolsonaro: sin Marx, sin el Che y sin repudio a la dictadura [Электронный pecypc] / V.D. López // El Diario. - URL: www.eldiario.es/internacional/ Educacion-Brasil-Bolsonaro-Marx-Che_0_843066559.html (дата обращения 03.05.2019).

17. McVicar, M. The Religious Right in America [Электронный ресурс] / M. McVicar // Oxford Research Encyclopedia of Religion. - URL: https://oxfordre.com/religion/oso/viewentry/10.1093\$ 002 facrefore $\$ 002$ f9780199340378.001.0001 \$002facrefore-9780199340378-e-97;jsessionid=1E0 9C5A478874B5D2530E2E664D3F121 (дата обращения 03.05.2019).

18. Parker, C. ¿América Latina ya no es católica? El incremento del pluralismo cultural y religioso. América Latina: Interrogantes y Perspectivas / C. Parker. -Universidad de York, Universidad de Valparaiso. - P. 205-232.

19. Pastor Gómez, M.L. El evangelismo en América Latina, un poder creciente. El caso de Brasil [Электронный ресурс] / Pastor M.L. Gómez // Documento de Análisis IEEE 42/2018. - URL: http://www.ieee.es/Galerias/fichero/docs_analisis/2018/DIEEEA42-2018EvangelMLPG.pdf (дата обращения 26.04.19).

20. Religion in Latin America [Электронный pecypc] // Pew Research Center. - URL: http:// www.pewforum.org/2014/11/13/religion-in-latin-america/\#history-of-religious-change (дата обращения 25.04.2019).

21. Sherwood, H. "Toxic Christianity": the evangelicals creating champions for Trump [Электронный ресурс] / H. Sherwood // The Guardian. - URL: www.theguardian.com/us-news/2018/oct/21/ evangelical-christians-trump-liberty-university-jerry-falwell (дата обращения 23.04.2019).

22. Smith, G.B. The Spirit of Evangelical Christianity / G.B. Smith // The Journal of Religion. 1922. - Vol. 2. - № 6. - P. 624-634. 


\section{История религии / History of Religion}

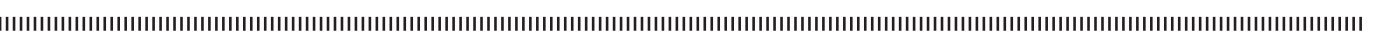

\section{References}

1.Bychkov A.A. Sotsial'naya kompetentnost'. Irkutskiy natsonal'ny issledovatel'sky tekhnichesky universitet [Social Competency. Irkustk National Research Technical University]. 2017, vol. 2, no. 1 (3), pp. 87-89 (in Russian).

2. Cantril H. Propaganda Analysis. The English Journal. 1938, no. 27(3), pp. 217-221.

3. Cariboni D. Guatemala Evangelicals Are Close to "Legalizing Homophobia" [Evangélicos en Guatemala al Borde de "Legalizar la Homofobia"]. Available at: https://elpulso.hn/evangelicos-enguatemala-al-borde-de-legalizar-la-homofobia/ (accessed on May 01, 2019) (in Spanish).

4. Castañeda J.M. Deputy Regrets Promoting the Day of the Evangelical Church [Diputada se Arrepiente de Promover el Día de la Iglesia Evangélica]. Available at: http://www.soy502.com/articulo/diputadaarrepiente-promover-dia-iglesia-evangelica-63338 (accessed on May 01, 2019) (in Spanish).

5. Corrales J. A Perfect Marriage: Evangelicals and Conservatives in Latin America. The New York Times. Available at: www.nytimes.com/2018/01/17/opinion/evangelicals-politics-latin-america.html (accessed on April 26, 2019).

6. De Jong A. Protestants decline, more have no religion in a sharply shifting religious landscape (POLL). $A B C$ News. Available at: http://www.abcnews.go.com/Politics/protestants-decline-religion-sharplyshifting-religious-landscape-poll/story?id=54995663 (accessed on April 23, 2019).

7. Evangelical Beliefs and Practices. Pew Research Center. Available at: http://www.pewforum. org/2011/06/22/global-survey-beliefs/ (accessed on April 16, 2019).

8. Filippini M., Barr P. Ideology In Using Gramsci: A New Approach. London: Pluto Press, 2017, pp. 4-23.

9. Freston P. Evangelicalism and Politics: A Comparison between Africa and Latin America. Transformation, no.14(1), pp. 23-29.

10. Galarriaga N. The New minister of Family of Brazil: "Pink is for Girls, Blue is for Boys" [La nueva ministra de Familia de Brasil: "Las niñas, de rosa; los niños, de azul"].Available at: elpais.com/ internacional/2019/01/04/actualidad/1546602274 498637.html (accessed on May 03, 2019) (in Spanish). 11. Guatemala Evangelicals Choose to Support Politically to the Party of Retired General [Evangélicos de Guatemala optan por apoyar políticamente a partido de general retirado]. Available at: www.aciprensa. $\mathrm{com} /$ noticias/evangelicos-de-guatemala-optan-por-apoyar-politicamente-a-partido-de-general-retirado (accessed on May 01, 2019) (in Spanish).

12. Guatemala Prohibits the Entry to a Swedish Metal Band for Being "Immoral" and "Satanic" [Guatemala prohíbe la entrada a una banda sueca de metal por "inmoral" y "satánica". Available at: http:// actualidad.rt.com/actualidad/290024-guatemala-prohibir-banda-marduk-suecia-satanico (accessed on May 01, 2019) (in Spanish).

13. Jewett A. Detecting and Analyzing Propaganda. The English Journal, 1940, no. 29(2), pp. $105-115$.

14. Lampman J. Renewalist impact grows. The Christian Science Monitor. Available at: http://www. csmonitor.com/2006/1012/p13s02-lire.html (accessed on April 16, 2019).

15. López V.D. Bolsonaro Education in Brazil: Without Marx, Che and Repudiation of the Dictatorship [Educación en el Brasil de Bolsonaro: sin Marx, sin el Che y sin repudio a la dictadura]. Available at: www.eldiario.es/internacional/Educacion-Brasil-Bolsonaro-Marx-Che 0 843066559.html (accessed on May 03, 2019) (in Spanish).

16. McVicar M. The Religious Right in America. Oxford Research Encyclopedia of Religion, 2016.

17. Parker C. Latin America: Questions and Perspectives [América Latina: Interrogantes y Perspectivas]. Universidad de York-Universidad de Valparaiso-Cis, pp. 205-232 (in Spanish).

18. Pastor Gómez M.L. El evangelismo en América Latina, un poder creciente. El caso de Brasil. Documento de Análisis IEEE 42/2018. Available at: http://www.ieee.es/Galerias/fichero/docs analisis/2018/DIEEEA42-2018EvangelMLPG.pdf (accessed on April 24, 2019) (in Spanish).

19. Pope Francisco and the Religion in Chile and Latin America [El Papa Francisco y la Religión en Chile y América Latina]. Available at: http://www.cooperativa.cl/noticias/site/artic/20180112/ asocfile/20180112124342/f00006494_religion_chile_america_latina_2017.pdf (accessed on April 30, 2019) (in Spanish).

20. Religion in Latin America. Pew Research Center. Available at: http://www.pewforum.org/2014/11/13/ religion-in-latin-america/\#history-of-religious-change (accessed on April 25, 2019).

21. Sherwood H. "Toxic Christianity": the evangelicals creating champions for Trump. The Guardian. Available at: www.theguardian.com/us-news/2018/oct/21/evangelical-christians-trump-liberty-universityjerry-falwell (accessed on April 23, 2019).

22. Smith G.B. The Spirit of Evangelical Christianity. The Journal of Religion. Vol. 2, no. 6, 1922, pp. 624-634. 